\title{
TEACHING COMMUNICATION STRATEGIES TO THE COMPUTER PROGRAMMING STUDENTS
}

\author{
Nataliya Mykytenko \\ Ivan Franko National University of Lviv, Lviv, Ukraine \\ natusiamykyt@gmail.com \\ Nataliia Rozhak \\ Ivan Franko National University of Lviv, Lviv, Ukraine \\ suwo@gmail.com \\ Iryna Semeriak \\ Ivan Franko National University of Lviv, Lviv, Ukraine \\ irinazhuk16@gmail.com
}

\begin{abstract}
The successful functioning of computer programming specialists largely depends on their level of communicative competence, so a university course of English for specific purposes (ESP), aimed at its development, can be exceedingly useful in professional training of future computer programmers. To optimise the process of ESP learning we have outlined the verbal addresser-oriented strategies (stimulating strategy, emotional activity strategy, evaluation activity strategy, cooperative strategy and strategy of self-presentation) and elaborated a system of exercises for their development. It includes the following stages: 1) studying general foreign language by means of communication strategies; 2) studying ESP by means of communication strategies. To validate the effectiveness of the system of exercise we conducted experimental teaching of the 1st and 2nd-year students of the Faculty of Applied Mathematics and IT Technologies at Lviv Ivan Franko National University in 2016-2017 academic year. It involved 144 participants. Efficiency of the system of exercises has been proved on the basis of the results obtained from pre- and post- experimental assessment of students from exposure groups and reference groups. Growth rate in students from exposure groups significantly exceeded the results in students from reference groups. Thus, the efficacy of the suggested system of exercises used for developing communication strategies in computer programming students has been proved.
\end{abstract}

Keywords: communicative competence; communication strategies; ESP; system of exercises; computer programming students.

\section{Introduction}

The successful functioning of computer programming specialists largely depends on their level of communicative competence, so a university course of English for specific purposes (ESP), aimed at its development, can be exceedingly useful in professional training of future computer programmers. Strategies as tools for active, self-directed involvement are essential for the development of communicative competence (Oxford, 2006, p. 1). To prepare language learners for real-life communicative contexts, it is important to teach them a set of strategies to overcome communication problems (Willems, 1987). This can be done in two ways, as stated by Willems (1987): the learners need to possess knowledge on a wide variety of communication strategies available and they should also practise them so that the use of communication strategies becomes automatic.

During the last decades, communication strategies have become a field of research for many scholars in the field of English as a foreign language (Canale \& Swain 1980; Canale, 1983; Willems, 1987; Dörnyei \& Scott, 1997; Kay, 2012; Chernysh, 2015; Rosas Maldonado, 2016; Montero, 2017; Martínez-Adrián, Gallardo-del-Puerto \& Basterrechea, 2017; Palmer \& Christison, 2018).

In particular Oxford (2006) and Stern (1975) classified strategies for learning languages, Tereshchuk (2013) applied communication strategies in the context of cognitive, sociocultural and action-oriented approaches, Batsevych (2004) described the features of communication strategies, Van Dijk (2000) outlined the types of strategies.

The concept of a communication strategy in applied linguistics is debated intensively and researchers haven't provided a consensus on its definition as well as on the typology of communication strategies (Dörnyei \& Scott, 1997). In this respect, it seems reasonable to provide several definitions of communication strategies. Cohen (2004) defines a communicative strategy as "a systematic attempt by the speakers or the learners to deliver or give the exact meaning that is not proportionate with the rules of the target language" (pp. 302-303).

Mykytenko N., Rozhak N., \& Semeriak I. (2019). Teaching communication strategies to the computer programming students. Advanced Education, 12, 49-54. DOI: 10.20535/2410-8286.167148 
For Færch and Kasper (1983), a communication strategy means something more than the ability to use appropriate linguistics resources of a target language in accordance with a particular communicative situation. According to their definition, communication strategies are "potentially conscious plans for solving what to an individual presents itself as a problem in reaching a particular communicative goal" (p. 36).

Based on the analysis of works (Batsevych, 2004, p. 133; Canale, 1983; Cernysh, 2015, p. 17; Færch \& Kasper, 1983, p. 36; Putri, 2013, p. 129; Tereschuk, 2013, p. 25), a communication strategy of ESP can be defined as an ability to implement the integrity of stage-by-stage thinking and speech activities aimed at the modelling by the participants of their own communicative behaviour in the context of professionally applied communication in a foreign language in order to achieve the goal of communication.

The analysis of academic sources (Batsevych, 2004, p. 52; Melnyk, 2011; Tereshchuk, 2013, p. 36) has proved that in the context of ESP learning of computer programming students it is practical to highlight the verbal addresser-oriented strategies: 1) informative strategy (aims at informing or receiving information, agreeing or disagreeing; influences the verbal or non-verbal behaviour of the interlocutor); 2) stimulating strategy (helps to direct the behaviour of the interlocutor, prompting him or her to the implementation of action such as argumentation, advice, request, claim etc.); 3) emotional activity strategy (helps to avoid stress and express an emotional state such as joy, approaval etc); 4) evaluation activity strategy (aims at monitoring and evaluating interlocutors' speech); 5) cooperative strategy (involves positive interdependence in the team of interlocutors for achieving a common aim through equal participation of the interlocutors, interaction and reflection) and 6) strategy of self-presentation (helps interlocutors to express their opinions, share experiences in the IT-field). The selection of these strategies is based on their correlation with the major communication functions (cognitive, evaluative, fatigue, social, psychological) in a foreign language.

As a result, these communication strategies play a crucial role in teaching ESP speaking and writing and the learning process has to be concentrated on developing communication strategies to the students.

For that purpose, we created a system of exercises for teaching communication strategies to computer programming students and this paper aims to verify its efficiency when used in an ESP course at university.

With this in mind, we hypothesise that ESP training of future computer programmers will be more successful with the use of a system of exercises that is focused on mastering communicative strategies.

\section{Methods}

\section{Participants}

In order to prove the efficacy of the system of exercises used to develop communication strategies of computer programming students, an experiment was conducted within which the results of the study were analysed. The experiment was conducted during autumn-winter semester of 2016-2017 academic year. It involved 144 participants who were $1^{\text {st }}$ and $2^{\text {nd }}$ year students of the Faculty of Applied Mathematics and IT Technologies at Lviv Ivan Franko National University, who were subdivided into five Exposure Groups (EGs) and five Reference Groups (RGs) which constituted five experimental pairs arranged respectively.

\section{Instruments and procedure}

Analysing the system as one of our key terms we consider principal features which characterise a system as the links between its elements, hierarchy of elements, fixed sequence, ability of system's elements to interact functionally. Considering the fact that functionality is one of the key characteristics of any system, the developed system of exercises is expected to assume systemic features. The functionality of the system of exercises is connected with the communicative organisation of the syllabus. Typical communicative situations are linked with the future profession of the computer programming specialists. Also, they enable students to develop their skills in the process of communicative interaction and to implement communication strategies in speech activity. Except these two characteristics this system has to have a clear structure, subdivision into components, hierarchy of components, correspondence with the aim and principles, subdivision into stages, interconnection and interconditionality of exercises, communicative bias in the process of ESP learning.

In our research we use the definition of the term exercise given by Nikolaieva, Bihych, Borysko and Boretska (2013): "specially organised multiple execution of separate operations, actions or activities in the process of learning that is aimed at mastering and improving of such operations, actions or activities" (p. 181).

The cornerstone of our system of exercises is its macro aim - to achieve a high level of acquisition of communicative competence (level B2) of the computer programming specialists in ESP course. The micro aims involve stage-by-stage mastering the language knowledge and skills, communication strategies that are necessary for the future profession of computer programming specialists. Additionally the micro aims require that students' communicative abilities should be further developed through more sophisticated 
communication strategies with consideration of students' cognitive features: dominant styles of learning, operation of long-term and short-term memory, concentration (ability to focus) (Mykytenko, 2011).

Since one of the key characteristics of the system of exercises is its subdivision into stages, the implementation of the system of exercises aimed at the use of communication strategies by the computer programming specialists in learning ESP must include the following stages: 1) studying general English by means of communication strategies; 2) studying ESP by means of communication strategies. Each of the stages is further subdivided into three substages: 1) introduction of the strategies to students; 2) automatic performance of speech actions with the use of communication strategies with particular focus on productive activities; 3) use of the strategies in communication. Within these stages, the students learn the types of communication strategies and how to use them in speech activities.

The system of exercises includes various groups and types of exercises, the purpose of which is teaching computer programming students to use the communication strategies through certain stages (Table 1).

Table 1. The system of exercises aimed at teaching computer programming students to use communication strategies

\begin{tabular}{|c|c|c|c|c|c|}
\hline \multicolumn{3}{|c|}{$\begin{array}{l}\text { Group 1 } \\
\text { to be done at Stage } 1 \\
\text { (General English) }\end{array}$} & \multicolumn{3}{|c|}{$\begin{array}{c}\text { Group } 2 \\
\text { to be done at Stage } 2 \\
\text { (ESP) }\end{array}$} \\
\hline \multicolumn{3}{|c|}{$\begin{array}{l}\text { Predominate communication strategies: } \\
\text { cooperative, informative, emotional activity, } \\
\text { stimulating }\end{array}$} & \multicolumn{3}{|c|}{$\begin{array}{c}\text { Predominant communication strategies: } \\
\text { cooperative, informative, evaluation activity, } \\
\text { self-presentation }\end{array}$} \\
\hline $\begin{array}{c}\text { Subgroup } 1 \\
\text { to introduce } \\
\text { communication } \\
\text { strategies to } \\
\text { students }\end{array}$ & $\begin{array}{l}\text { Subgroup } 2 \\
\text { to make the } \\
\text { students' use of } \\
\text { communication } \\
\text { strategies } \\
\text { automatic }\end{array}$ & $\begin{array}{c}\text { Subgroup 3 } \\
\text { to use } \\
\text { communication } \\
\text { strategies in } \\
\text { communicative } \\
\text { activity }\end{array}$ & $\begin{array}{l}\text { Subgroup 1 } \\
\text { to introduce } \\
\text { communication } \\
\text { strategies to } \\
\text { students }\end{array}$ & $\begin{array}{l}\text { Subgroup } 2 \\
\text { to make the } \\
\text { students' use of } \\
\text { communication } \\
\text { strategies } \\
\text { automatic }\end{array}$ & $\begin{array}{c}\text { Subgroup 3 } \\
\text { to use } \\
\text { communicatio } \\
\text { n strategies in } \\
\text { communicative } \\
\text { activity }\end{array}$ \\
\hline \multicolumn{3}{|c|}{ Types of exercises } & \multicolumn{3}{|c|}{ Types of exercises } \\
\hline $\begin{array}{c}\text { receptive } \\
\text { provisionally } \\
\text { communicative }\end{array}$ & $\begin{array}{l}\text { receptive } \\
\text { reproductive } \\
\text { provisionally } \\
\text { communicative, } \\
\text { receptive } \\
\text { reproductive } \\
\text { communicative }\end{array}$ & $\begin{array}{c}\text { productive } \\
\text { provisionally } \\
\text { communicative, } \\
\text { productive } \\
\text { communicative }\end{array}$ & $\begin{array}{l}\text { receptive } \\
\text { provisionally } \\
\text { communicative }\end{array}$ & $\begin{array}{l}\text { receptive } \\
\text { reproductive } \\
\text { provisionally } \\
\text { communicative, } \\
\text { receptive } \\
\text { reproductive } \\
\text { communicative }\end{array}$ & $\begin{array}{c}\text { productive } \\
\text { provisionally } \\
\text { communicative, } \\
\text { productive } \\
\text { communicative }\end{array}$ \\
\hline
\end{tabular}

The exercises in Group 1, Subgroups 1, 2, and 3 of the system are aimed at the development of basic communication strategies (cooperative, informative, emotional activity, stimulating) in studying general English. The exercises of Group 2, Subgroups 1, 2, and 3 are focused on the following strategies: cooperative, informative, evaluation activity, self-presentation. Subgroup 1 includes: reading texts retrieved from online resources for acquiring new professional information; listening to audio and watching video materials. The exercises of Subgroup 2 include: gap filling; building of associative chains with the aim of producing communication strategies through brainstorming. The exercises of Subgroup 3 include: business writing, online chat room learning in oral and in written forms; briefing; debriefing; role playing; simulations; projects; presentations.

The integral component of any exercise in the suggested system is a communicative situation that has to meet the following requirements: to be based on the communicative approach; to reflect professional realities of communication that requires the use of communicative strategies; to motivate students to perform the assignment; to use whole class work, group work, pair work and independent study; to provide scaffolding (if it is necessary).

In order to teach the students to find the proper communication strategy in each specific communicative situation, it is suggested that the addressee use the corresponding algorithm (Figure 1). 


\begin{tabular}{|c|l|l|}
\hline \multicolumn{2}{|c|}{\begin{tabular}{|l|} 
Algorithm for usage of communication strategies: informative, stimulating, \\
emotional activity, evaluation activity, cooperative \\
and self-presentation strategies
\end{tabular}} \\
\hline Step 1
\end{tabular}

Figure 1. Algorithm of teaching communication strategies application

The elaborated algorithm for selection and application of corresponding communication strategies has proved to be more efficient in the process of independent work on writing assignments, particularly, writing messages, private and business/formal correspondence, reports etc. It has also proved effective in the process of oral communication. At the initial stages of teaching, students had sufficient time to undertake and accomplish a stage by stage analysis and implementation of the suggested steps. At the further stages of the experiment, students began to use the suggested steps automatically, with no particular extra effort.

For the implementation of the suggested methodological procedures, the experimental materials were devised, specifically: testing tasks (Task 1: to write an essay; Task 2: to roleplay a dialogue; to create a monologue) to define the level of foreign language proficiency of students; criteria for evaluation of speaking (lexical, grammatical and phonetical correctness; coherence; content) and writing (lexical and grammatical correctness; coherence; content) skills with the use of scale from 1 to 100. In the experiment, we also used the following techniques: briefing, debriefing, role-playing, simulations (in class) and online chat learning facilitated by a professor (extracurricularly).

\section{Results}

To prove the efficacy of the system of exercises used to develop communication strategies of computer programming students, an experiment was conducted. Figures 2 and 3 show the pre- and postexperimental results of Exposure Groups and Reference Groups which made up five experimental pairs arranged respectively. 


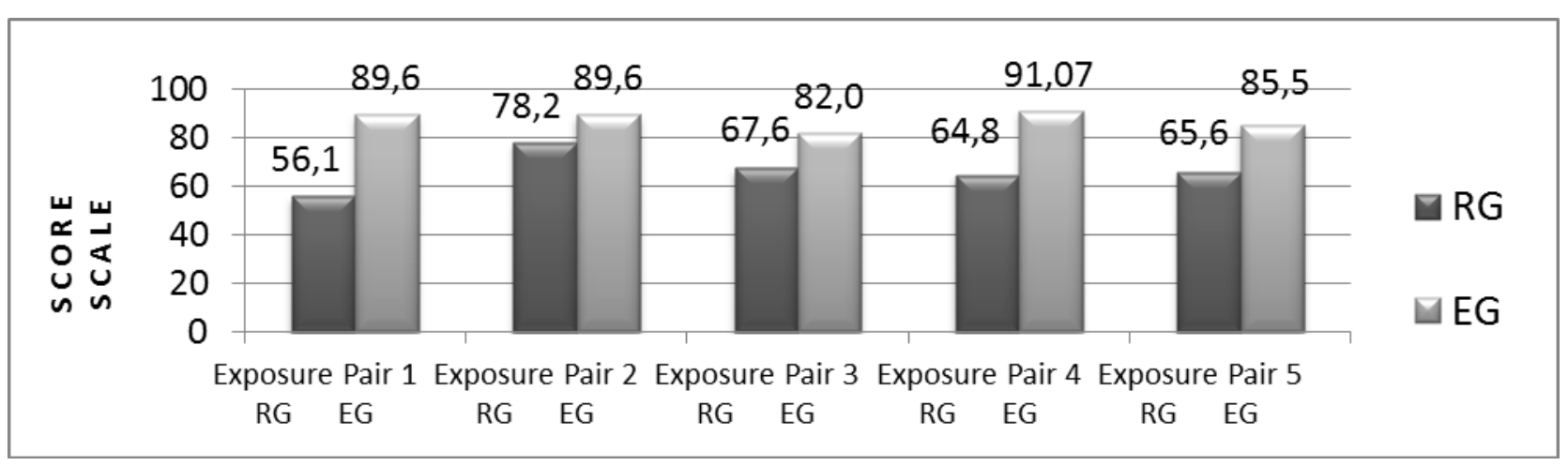

Figure 2. Results of teaching communication strategies in Exposure and Reference Groups obtained through statistical analysis upon completion of the experiment

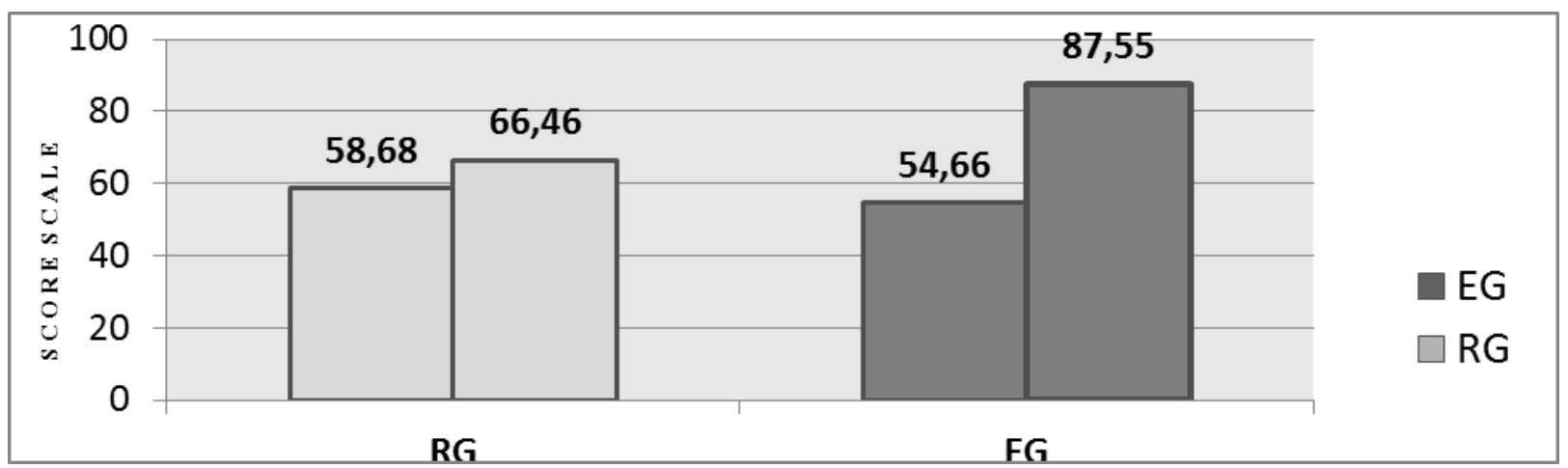

Figure 3. Growth patterns due to using communication strategies in Exposure and Reference Groups derived from mean values obtained through statistical analysis before and after the experiment

The obtained results have been verified using mathematical statistics methods. The growth rate due to using communication strategies in students of the Exposure Groups significantly exceeds the growth rate in students from the Reference Groups in all experimental pairs.

According to the data obtained from the calculation of mean values before and after the experiment for all Exposure and Reference Groups, Student's $t$-test criterion amounted to 5.4 and was within the significance range whereas Mann-Whitney $U$ test criterion value amounted to 0 and was also within the significance range.

Interpretation of the results before and after the experiment allowed us to prove the validity of the hypothesis of the experimental research.

\section{Discussion and Conclusions}

The analysis of the results of our study allowed us to single out some arguments which, in our opinion, can show the effectiveness of the developed system of exercises for teaching communication strategies to computer programming students.

Firstly, the hierarchy of exercises allows the students to learn the types of communication strategies and step-by-step develop the skills of using them in professional communication.

Secondly, the use of communication strategy influences the process of communication. We agree with Oxford (2006) who considers them "as specific actions taken by learners to make learning easier, faster, more enjoyable, more self-directed, more effective, and more transferable to new situations" (p. 8). Based on our experience we may argue that mastering the communication strategies gives an opportunity to engage the mechanism of preventive displaying, the essence of which relies on foreseeing the anticipated communicative behaviour of the addressee as well as foreseeing and modelling the communicative behaviour of addresser in order to ensure the efficacy of the process of ESP acquisition.

Thirdly, the suggested system of exercises implies the use of communicative foreign language learning methods: business games including role plays and simulations, presentations, reports, briefings, debriefings, online chat learning which allow students to use a wide range of communication strategies.

Our research has certain limitations since we focused only on particular communication strategies: 1) informative strategy; 2) stimulating strategy; 3 ) emotional activity strategy; 4) evaluation activity strategy; 5) cooperative strategy and 6) strategy of self-presentation. On the other hand, we did not focus on the 
cognitive styles of students which are important to take into account when developing communication strategies. This aspect was particularly highlighted by Bondar (2011) who outlined two groups of strategies (A) learning strategies adapted to the features of students' dominant learning styles, (B) learning strategies aimed at improving the students' learning styles - and showed that the development of the flexibility of learning style of future engineers is the basis for effective ESP teaching (p. 16). The strategies used in Bondar's (2011) and our research were different, but all of them proved their efficiency so the problem of cognitive style in teaching communication strategies can be the subject of our further study.

As a result, the development of the ability to use communication strategies is especially important in teaching computer programming students to successfully communicate in English in their professional environment. The proper use of communication strategies by students implies their ability to implement the integrity of stage-by-stage thinking and language activities which include the modelling of interlocutors' communicative behaviour in the context of ESP to achieve the goal of communication. With this in mind, we created a system of exercises which was used in the course of ESP at our university and proved efficient for teaching communication strategies to computer programming students.

\section{References:}

Bondar, L. V. (2011). Metodyka navchannya franczuzkogo profesijno spryamovanogo monologichnogo movlennya studentiv texnichnyx specialnostej z uraxuvannyam yix navchalnyx styliv [Methodology of teaching French professional oriented monologue to students of technical specialties taking into account their educational styles]. PhD dissertation abstract, Kyiv National Linguistic University, Kyiv, Ukraine.

Batsevych, F. S. (2004). Osnovy komunikatyvnoi lingvistyky [Fundametals of communicative linguistics]. Kyiv, Ukraine.

Canale, M. \& Swain, M. (1980). Theoretical bases of communicative approaches to second language teaching and testing. Applied Linguistics, 1(1), 1-47. https://doi.org/10.1093/applin/1.1.1

Canale, M. (1983) From communicative competence to communicative language pedagogy. Language and Communication, 2-27.

Chernysh, V. V. (2015). Teoretyko-metodychni zasady formuvannia u maibutnich uchyteliv profesiino orientovanoi anglomovnoi kompetentnosti $v$ hovorinni [Theoretical and methodological foundations of future teachers' professionally oriented competence in English speaking formation]. Dissertaion abstract, Kyiv National Linguistic University, Kyiv, Ukraine.

Cohen, A. (2004). Assessing speech acts in a second language. In Boxer, D., \& Cohen, A. D. (Eds.), Studying speaking to inform second language learning (pp. 302-327). Clevedon, England: Multilingual Matters.

Dörnyei, Z., \& Scott, M. L. (1997). Communication Strategies in a Second Language: Definitions and Taxonomies. Language Learning, 47(1), 173-210. https://doi.org/10.1111/0023-8333.51997005

Faerch, C., \& Kasper, G. (1983). Plans and Strategies in Foreign Language Communication. In C. Faerch, \& G. Kasper (Eds.), Strategies in Interlanguage Communication (pp. 20-60). New York: Longman.

Kay, S. (2012). Communication Strategies: Learning and Teaching. How to Manage Oral Interaction. ELT Journal, 66(3), $409-411$. https://doi.org/10.1093/elt/ccs026

Rosas Maldonado, M. (2016). Communication strategies used by different level L2 English learners in oral interaction. Revista Signos, 49(90), 71-93. https://doi.org/10.4067/s0718-09342016000100004

Martínez-Adrián, M., Gallardo-del-Puerto, F., \& Basterrechea, M. (2017). On self-reported use of communication strategies by CLIL learners in primary education. Language Teaching Research, 23(1), 39-57. https://doi.org/10.1177/1362168817722054

Melnyk, I. V. (2011). Typy komunikatyvnykh stratehii [Types of communicative strategies]. Studia Linguistica, 5(2), 377-380.

Montero, L. (2017). Developing effective L2 communication strategies abroad and at home. The Language Learning Journal, 1-11. https://doi.org/10.1080/09571736.2017.1357744

Mykytenko, N. (2011). Teoretychni osnovy formyvannia inshomovnoi profesiinoi kompetentnosti maibutnikh fachivtsiv pryrodnychykh spetsialnostei [Theoretical foundations of forming professional foreign language competence of prospective specialists of Sciences]. Ternopil, Ukraine: TNPU.

Nikolayeva, S. Yu., Bihych, O. B., Borysko, N. F., \& Boretska, H. E. (2013). Metodyka navchannia inozemnykh mov i kultur: teoriia i praktyka: pidruchnyk dlia studentiv klasychnykh, pedahohichnykh i linhvistychnykh universytetiv [Teaching methods of foreign languages and cultures: theory and practice]. Kyiv, Ukraine: Lenvit.

Oxford, R. (2006). Language Learning Strategies: What Every Teacher Should Know. Heinle \& Heinle Publishers.

Palmer, A. S. \& Christison, M. A. (2018). Communication strategies and teaching speaking. In M.A. Christison \& C. Broady (Eds.), The TESOL Encyclopedia of English Language Teaching (pp.1-6). Wiley/Blackwell. https://doi.org/10.1002/9781118784235.eelt0708

Putri, L. A. (2013). Communication Strategies in English as a Second Language (ESL) Context. Advances in Language and Literary Studies, 4(1), 129-133. https://doi.org/10.7575/aiac.alls.v.4n.1p.129

Stern, H. H. (1975). What can we learn from the good language learner? Canadian Modern Language Review, 31(4), 304-319. https://doi.org/10.3138/cmlr.31.4.304

Tereshchuk, D. H. (2013) Formyvannia u stedentiv filolohichnykh spetsialnostei inshomovnykh komunikatyvnykh strategii $z$ vykorystanniam movlennevykh symuliatsii [Building in students of philological specialties foreign language communicative strategies with the use of simulations]. PhD thesis, Ternopil National Pedagogical University named after Volodymyr Hnatyuk, Ternopil, Ukraine.

Van Dijk, T. (2000) Ideology: A Multidisciplinary Approach. London: SAGE. https://doi.org/10.4135/9781446217856.

Willems, G. M. (1987). Communication strategies and their significance in foreign language teaching. System, 15(3), 351-364. https://doi.org/10.1016/0346-251X(87)90009-1 